\title{
Introduction: the sound(s) of politics
}

\author{
Dean Cooper-Cunningham, Ph.D. Fellow, Department of Political Science, University of \\ Copenhagen
}

Livingston, March/April 2020

We often lose so much of ourselves in the pursuit of science, in the writing of knowledge, in the production of (a) 'truth'. So much so that, more often than not, the aesthetic and affective registers through which we come to know and engage with the (global) political issues that we study fall out of the final products we produce - the articles, book chapters, edited volumes, lectures, and so on (Bleiker 2009; Åhäll 2018). That is why this special issue on music and politics starts with my own aesthetic and affective encounters with music and its politicality. For readers, this will hopefully serve less as a self-indulgent exercise and more as an exploration of (global) politics, music, and the personal. What follows is a bricolage of personal memory snippets about how music and (international) politics intersect ${ }^{1}$.

As I write the introduction to this insightful, inspiring collection of essays and conversation pieces that centre on the sound(s) of politics, we are in the midst of the coronavirus pandemic. In fact, I write this from the small pavilion in my parents' back garden where I am quarantined for fourteen days. At times like these existential questions arise, productivity (rightly) nosedives, and we start to reassess what is important as the people around us are differentially affected by the virus. It becomes important just to make it through, not to produce ground-breaking scholarship. However, this special issue on the sound(s) of politics offers an apt space to comment on one of the things to come out of the Covid-19 pandemic that I am struck by: how music has been a central feature of our response.

Upon noticing that music was a central feature to weathering the Covid-19 storm, I was provoked to trace my thoughts and ways of encountering the relationship between music and politics over the years. In this introduction, I will first elaborate on some of the ways that music is being used during the pandemic to illustrate the links between musica seemingly mundane part of popular culture - and (international) politics. Then, reifying the feminist mantra that the personal is political, I reflect on my own encounters with music as (international) politics.

\footnotetext{
${ }^{1}$ Thanks to Laura Holderied for constructive feedback and conversation on this point.
} 
As the potential scale of coronavirus started to become clear, the UK's NHS' and USA's $\mathrm{CDC}^{3}$ told its citizens to ensure they washed their hands for a full twenty seconds by singing 'Happy Birthday'. One social media user created a website called 'Wash Your Lyrics', which generates a hand-washing technique poster complete with lyrics to any song of your choosing, allowing you to sing along while you scrub ${ }^{4}$.

As Europe went into lockdown, videos emerged of Italians having collective singalongs from their balconies - as had also happened in Wuhan but with much less European media attention - sparking a global trend in music as a way of 'getting through' (Kearney 2020). Since then music has become one of the unacknowledged beacons of the pandemic, at least in Europe. Testament to this, Rotterdam's Philharmonic Orchestra, the Orchestre National de Lyon, La Scala's Philharmonic Orchestra, Orchestre National de France, and the UK's Royal Opera House Orchestra and Chorus have all used social media to put on virtual concerts (Tilden 2020). Both to distract some attention from the pandemic in a moment of respite and to fulfil cancelled concerts.

In the UK, the BBC's Radio arm has coordinated a cross-station singalong for key workers "designed to lift spirits during the lockdown" (BBC 2020a). This inadvertently exposed the overwhelmingly white, middle-to-upper class Radio 2 listeners to the sounds of the BBC Asian Network. This alone speaks to the ways that sound is political. In Glasgow, an Elvis impersonator performed a coronavirus gig from his balcony before being interrupted by police (Hammil 2020). The accompanying video suggests this was from a social housing estate, raising questions about class inequalities and access to outdoor (green) spaces such as a personal garden. On this, UK policing strategies have been criticised for the discriminatory punishment of those without private gardens as many were berated for using communal parks for activities other than their government-sanctioned sixty minutes of daily exercise (Moore 2020). Such inequalities and the governments' presumption about the ease of working from home have been addressed variously across social and news media (Hanley 2020). In another important turn, which speaks to the emotional and political power of music, Queen Elizabeth II referenced Vera Lynn's wartime classic 'We'll Meet Again', professing that: "we will be with our friends again, we will be with our families again, we will meet again" (BBC 2020b).

More globally, music streaming services from Spotify to Apple Music have launched lockdown playlists. Apple, for example, launched 'At home with Apple Music', which features interviews with artists about their specially curated playlists. Some of these critique governments' responses to the crisis either directly or implicitly. Two notable music artists - Troye Sivan and Charli XCX - have used the lockdown to collaborate with creatives who would ordinarily be excluded from the music industry (Buzzfeed 2020; Rolling Stone 2020). Others still have remixed popular songs to spread messages

\footnotetext{
${ }^{2}$ https://www.nhs.uk/live-well/healthy-body/best-way-to-wash-your-hands/

${ }^{3} \mathrm{https}: / /$ www.cdc.gov/handwashing/when-how-handwashing.html

${ }^{4} \mathrm{https}: / /$ washyourlyrics.com/
} 
of solidarity and to reiterate lockdown guidelines ${ }^{5}$. In the case of the latter, they've almost become involuntary spokespeople for the government - an inherently political act, even if well intended and essential in "flattening the curve". Lady Gaga, who I discuss later, partnered with the World Health Organisation and Global Citizen to curate a digitally broadcast gig 'One World: Together at Home' to support the fight against Covid-19.

These examples are not exhaustive of the ways music has been used during the coronavirus pandemic and I list them to show the extent of music's impact in these testing times across all political spatialities from the individual, national (UK), regional (Europe), to the global. The politics of some of these examples may not be clear on the surface. One might suggest that music is simply filling the role of entertainment, a distraction from the news and scenes in hospitals the world over; just more mundane popular culture. Yet, all of these examples are political in their own ways, touching on themes such as empire (the Queen's speech), social inequality, race and ethnicity, capitalism, and the (international) political economy of music, amongst many others. Here, I will take the BBC singalong example, which focuses on celebrating key workers, and Troye Sivan and Charli XCX's lockdown music projects.

First, let's look at BBC Radio. Each week, one group of workers is celebrated in this national singalong. As I write this, we've just had a singalong for delivery drivers, those keeping us stocked up on essentials and supplying the books, newly repopularised jigsaw puzzles, games consoles, garden games, and the like to get us through the pandemic. The BBC's celebration of key workers, which has mostly focused on healthcare staff, comes in the context of parliament's rejection of pay rises and proposed post-Brexit immigration rules, which would class so many of these newly categorised 'essential workers' (in waste management, supermarkets, nursing, transport, factories) as 'unskilled' and unable to migrate to the UK. During the pandemic, these "unskilled" workers, as the British government had previously labelled them, have rightly been recognised as those who keep the country running (O'Carroll et al. 2020). And not just in times of crisis. In this sense, music has become a site for exploring societal inequalities and class politics. Music has become a way of subtly demanding increased funding for the NHS, which under the Tory government has been gutted, and it has become a way of reintroducing a sense of community with our neighbours, families, and peers through community singalongs and dancing that has been almost eradicated in the past two decades.

Also highlighting global socioeconomic inequalities, Troye Sivan and Charli XCX's respective 'lockdown' music projects sees both artists creating music with fans and those in the creative arts that they would otherwise have never connected with prelockdown. Their projects highlight the drastic inequalities in the creative arts and how the sector has become even more precarious in the years since the global financial crisis. These inequalities persist not just in terms of barriers to access but also in terms of personal and global economy. Many in the creative arts rely on the so-called 'gig economy'

\footnotetext{
${ }^{5} \mathrm{https}: / /$ www.instagram.com/p/B_ABffbodac/?utm_source=ig_web_copy_link https://twitter.com/thekillers/status/1239362297304207361

https://www.refinery29.com/en-us/2020/03/9593092/handwashing-songs-changed-lyrics
} 
and are in unsecured work: this lockdown leaves many without a source of income, leading to further (gendered, racialised, and classed) inequalities, particularly vis-à-vis health care in this moment. Most governments have yet to announce bailouts or safety nets for (those in) the arts sector, still cash strapped from cuts and disdain for government-backed arts projects since 2008. Yet those same governments have been fast to secure big corporations. This raises questions about who wins, who loses, power, precarity, inequality, and political-economic priorities not just during this pandemic but in 'normal' times. The gendered-racialised-classed politics of the music industry-how music is distributed, its political economy, access, rights, who listens to what, and so on - are similar to that in the film industry, which I have too little space to explore in depth (for an interesting discussion on the political economy of film, see Harman 2019).

I started with this example of coronavirus to highlight one of the various ways music can be political and how politics runs deep in the way we 'cope' with coronavirus. Next, I turn to other encounters with music as politics.

\section{Livingston, May 2011}

Turning back to a different period in my musical and political life, it's May 23, 2011. I've recently turned seventeen and I'm preparing to sit the most important exams of any Scottish teenagers' life; they'll determine whether I get into university or not. I'm at home studying and I'm listening to BBC Radio 1. Apart from it being a regular Monday, today Scott Mills gets the first play of the lead single from Lady Gaga's third studio album. Little to my knowledge the album had already leaked in its entirety. I don't remember the exact time but there's a big build up and then Gaga's voice sings: "It doesn't matter if you love him, or capital H-I-M...'cause you were born this way, baby," later continuing "no matter gay, straight, or bi, lesbian, transgender life, I'm on the right track baby, I was born to survive". This wasn't the first time Gaga had explored queerness in her musicrecall Poker Face and her proclamation that she was "bluffin' with [her] muffin"-but it was the first time $I$ had heard a mainstream artist offer up a queer space, an anthem that I could, at least then, identify with.

Today, I can see how the song has many flaws and can be problematic. One being how it essentialises sexuality, making it innate, unchanging, fixed, and some biologically pre-determined 'identity' (Altman 2019: 19). While its goals may be emancipatory and celebratory, the song is somewhat a product of its time, ignoring the possibility that sexuality, like gender, is a practice, a doing, that is fluid and evolving. However, it did receive critical acclaim. Elton John lauded it as "new gay anthem" (Jonze 2011). Anyone who frequents queer spaces will know this to be true: it is indeed one of the queer bops of the millennial era, despite its potentially problematic messaging. Out of every sound I'd listened to, this was one of the most overtly political songs, and albums, that I could identify with and carved out a queer space of self-acceptance. This is quite the feat given that I fell asleep listening Bob Marley as a baby/toddler and grew up surrounded by the sounds 
of other incredibly political artists such as The Clash, Ramones, Madness, The Who, The Kinks, The Specials, and Crass.

Importantly, the 'Born This Way' album came on the back of Gaga's fierce campaigning for the repeal of the infamous 'Don't Ask, Don't Tell' policy in the US armed forces, which allowed members to serve so long as they were not openly homosexual. Again, supporting a repeal of DADT is somewhat problematic and antithetical to some queer feminist politics, which problematise militarism for all the gendered, racialised, sexualised power politics it underpins and (re)produces. That said, for all the talk of "jumping on the queer bandwagon," Gaga, though not the first pop artist to do so, has been an advocate of equality and supporting the queer community. A repeal of DADT and same-sex marriage are both symbolic wins for queer people, even if problematic for supporting heteronormative (militarised) structures.

This all speaks to the (musical) politics of power. While the execution of her support for the queer community may be flawed at times and the music at times problematic, if we take a step back from academe and elitist, often exclusionary, queer studies (Brim 2020), that song, the album (which makes implicit reference to Hair that Dennis Altman discusses later), and Gaga's openly political stance, did something for those exploring their sexual 'self', figuring out their political space in the world, and fighting for acceptance and the right to live and thrive. There's a politics both in celebrating such work and in writing it off as problematic and refusing to engage it for what it is: an artist's desire to stick it to the heteropatriarchal system.

As JJ Halberstam argues: "This punk or wild [Gaga] feminism hints at a future rather than prescribing one; it opens out onto possibilities rather than naming them; it gestures toward new forms of revolt rather than patenting them" (2012: xiii). It pushes feminisms towards queer as well. My confrontation with Lady Gaga's music and its politics also highlights Annika Bergman Rosamond's point in this issue that: "musical activism is often associated with mainstream popular culture rather than plights of indigenous musicians" (Bergman Rosamond in this issue, 71).

\section{St Andrews, September 2015}

During my final undergraduate year, I took Caron Gentry's course on Gender and Terrorism. Caron showed us two music videos to establish the gendered nature of politics: Kasey Musgraves 'Follow Your Arrow'6 and Grace Petrie's 'Farewell to Welfare'7. Both were folk/country singers, relatively conservative genres, of roughly the same age who took different approaches to being political in their music. Kacey Musgraves is quite cleverly outspoken, albeit in a sanitised and cautious manner, with her lyrics "if you don't save yourself for marriage you're a ho-rrible person," which explicitly targets political

\footnotetext{
${ }^{6} \mathrm{https}: / / \mathrm{www}$. youtube.com/watch? $\mathrm{v}=\mathrm{kQ} 8 \mathrm{xqyoZXCc}$

${ }^{7} \mathrm{https}: / / \mathrm{www}$.youtube.com/watch?v=CkNT3ktaX7Y
} 
questions around religion, sex, marriage, and by extension patriarchy. Grace Petrie's body reads as queer, gender non-conforming. Petrie sings about the UK welfare system and its ravaging at the hands of the Conservative government. While slightly different in their approaches, they both sing about gendered and sexualised norms, and how supposedly more inclusive, diverse politics marginalises and affects.

Petrie's performance and appearance read as 'masculine' in a heteropatriarchal matrix, opening up questions about our perceptions of masculinity/femininity, gender/sex, identities. Musgraves' is quite stereotypically 'feminine', perhaps a political move to play within the gendered logics of the system as a means of subverting it. Both sing about different, albeit similar, political issues in their respective countries (US and UK). While Musgraves' work might be considered as mainstream, Petrie does not have a multimillion dollar record deal and their work might be read as more political because of its anarchistic lyrics and titles. These two artists push us to think: Why do we categorise some music as political and some as apolitical? What makes it political? Did they intend it as political or did it become so? Did we receive it as political? Were we aware it was political? And, if we take seriously Barthes' (1977, 142-148) point about polysemy and the death of the author, what does that mean in terms of audience, production, and circulation? These questions speak to the goals of this special issue, which explores how music is not just political in its lyrics but its performance, reception, and composition.

Copenhagen/Melbourne, 2020

When teaching gender, sexuality, and sex, I often use clips from RuPaul's Drag Race to demonstrate the social construction of gender/sex and to explain Judith Butler's performativity (Butler 1990). In my own work on the politics of belonging and identity in the USA, I have explored what it means to 'be American' in ways that are different from the Geroge W. Bush Administration's construction of white, heterosexual, cisgendered Americanness (Cooper-Cunningham 2020). In Season 10 of RuPaul's Drag Race (2018), the four final contestants are tasked with recording and performing a version of RuPaul's 'American', which speaks to this very question: what is it to be 'American'?

All four contestants wrote their own lyrics. Some of these reproduce standard Americanisms about liberty, freedom, and the American Dream but they also simultaneously push against the racialised, heteropatriarchal, immigrant-loathing structures governing what 'American' means. This all takes place in the context of a Trump presidency, which adds an obvious layer of politicality to the performance of lyrics that I need not unpack here.

The lyrics, performance, and composition of this Drag Race finale are key to destabilising - queering - the logics of 'Americanness' and asserting the ways that the nation is performed through and upon individual bodies. I could write at length on this song

\footnotetext{
${ }^{8} \mathrm{https://www.youtube.com/watch?v=sTakd0y0Qnc}$
} 
and its performance but let me highlight just a few aspects. In performance terms, this is four queer men dressed in drag - a highly politicised and often problematic practicesinging about being American, "the red, white, and blue," in a way that destabilises the popular image of acceptable US-American citizenship (see: Puar and Rai 2002; Puar 2007; Weber 2011). It is replete with salutes and military-style dance moves (see Baker in this issue) but it is also gender-norm-subordinating; it is queer through and through.

In its musical composition (see Franklin in this issue), a military parade-style drumbeat underpins key parts of the song where contestants sing "I am American... the red, white, and blue" (ca. 1min20s), highlighting the inseparability of Americanness and militarised culture. In lyrical terms, Eureka is perhaps the most (queerly) political: "It's not about your color, gender, or size / But if we come together, we can rise / I came from nothing, made me wanna scream / But I fought for my piece of the American Dream / You can be a stripe and get in line / Or be a star and not be defined" (ca. 1min 40s). The reference to the US flag, here, highlights the identity politics of difference in the US as well as the imagined nature of the nation: you can be a star or get in line but at the end of the day, we are all American. These lyrics emphasise the struggle in being recognised as an acceptable body, an acceptable American citizen in ways that confound a Trumpian vision of Americanness.

\section{Livingston, April 2020}

Turning to the contents of the special issue rather than engaging with its subject, there are three article-length takes on the politicality of music and three conversation pieces, all centring on the sound(s) of politics. Catherine Baker takes a queer approach to the study of music and politics, drawing on work from IR on popular culture as well as feminist and queer theories. Baker offers an analysis of militarism in Rihanna's Hard music video, connecting visual politics, aesthetics, and feminist and queer approaches on militarism that unpacks how this video and other popular-cultural artefacts using militarised aesthetics do political work. Drawing on a queer and feminist curiosity, Baker's article links nicely to Marianne Franklin's by introducing a focus on "elements of audiovisual and musical meaning which are rarely appreciated as significant in international politics: the synchronisation of sound, moving image and performance" (Baker in this issue: 31 ).

Franklin's focus on music-making and performance emphasises that we must examine the politics of production and composition as well as modes of performance, musical arrangements, and performance contexts in addition to reception and lyrics. In her article, Franklin uses the song 'My Way' and its various incarnations to reveal the underlying politics of music-making, arguing that: "the making of music can both reveal and resist incumbent powers at the nexus of political and cultural life" (Franklin in this issue 52).

Then, Annika Bergman Rosamond ties together postcolonial and feminist work with her interest in celebrity to study Sweden's colonial subordination of the Sami people. 
Exploring mining, colonisation, and music, Bergman Rosamond analyses Sami musician Sofia Jannok's efforts to decolonise the Sapmi area of Sweden through music. She shows how Jannok uses musical alongside activist political statements to destabilise hegemonic tales of the Swedish nation as an exceptional 'good state' and its moral credentials as a rights-giving, caring welfare state.

Turning to the Conversations section of the special issue, authors were given free reign to do as they so wished. The aim of this section was to provoke interesting discussions and push boundaries through shorter think pieces. First in the section, and following Bergman-Rosamond's postcolonial approach, Dina AlAwadhi and Jason Dittmer examine the relationship between Led Zeppelin's Immigrant Song and the Marvel Cinematic Universe's Thor: Ragnarok. In an important provocation, the authors examine how music inspires the politics of other media, such as film. They go on to argue that using Immigrant Song twice in the Marvel film highlights the theme of empire that runs through much of the Marvel cinematic universe. In this sense, the soundtrack is part of a postcolonial subversion of the superhero genre.

Simon Philpott turns to musical politics in Australia. Exploring Indigenous artists' work and the negotiation of racialised colonial legacies, Philpott argues that "along with sports, music is one way that Indigenous peoples have found their way into the hearts, and minds, of other Australians" (Philpott in this issue: 94). This thorough conversation piece prompts questions about imagining the nation's pasts, presents, and futures through music as well as the ways that music is used to navigate, bring attention to, and protest highly exclusionary and racist politics. In apt conclusion, which highlights the polysemous politics of all discourse, Philpott notes the unending challenge of knowing "there may be something happening here, but what is not exactly clear" (Philpott in this issue: 98).

And, lastly, Dennis Altman takes us through the politics of musicals, noting that Hamilton, although lauded for its politicality, is not the first to engage with politics. Altman deftly traces how the musical is a key site (and sight) of politics from Broadway to London's West End and beyond. By showing how musicals bring together multiple genres of music, Altman demonstrates the transboundary nature of the musical, how it defies rigid music genres and confronts politics in many different ways. Doing so, he argues that the musical is not just light entertainment but "a form which sometimes allowed politically difficult subjects to be put before a wider audience" (Altman in this issue: 100). Altman unpacks the various politics at play in several productions, knitting together several key political themes touched on in the issue - sexuality and gender, race, class, war, and revolution - and reiterating the key argument running through this special issue: music is political and we must tune into the sound(s) of politics. 
References

Åhäll, L. (2018). Affect as Methodology: Feminism and the Politics of Emotion. International Political Sociology, vol. 12(1), pp.36-52. https://doi.org/10.1093/ips/ olx024

Altman D. (2019). Unrequited Love: Diary of an Accidental Activist. Victoria: Monash University Publishing.

Barthes, R. (1977). Image, Music, Text. New York: Hill and Wang.

BBC (2020a). BBC radio stars lead the nation in a mass singalong. BBC News. Available at: https://www.bbc.com/news/entertainment-arts-52131810 [Accessed 02.04.20]

BBC (2020b). The Queen's Coronavirus broadcast: 'We will meet again' - BBC. United

Kingdom. Available at: https://www.youtube.com/watch?v=2klmuggOElE\&feature=youtu.be [Accessed 05.04.20]

Bleiker, R. (2009). Aesthetics and world politics. Basingstoke: Palgrave Macmillan.

Brim, M. (2020). Poor Queer Studies. Duke University Press.

Butler, J. (1990). Gender Trouble: Feminism and the Subversion of Identity. New York: Routledge.

Buzzfeed (2020). Troye Sivan Is Releasing New Music So He Can Work With Freelance Artists And Give Back To The Community. Available at: https://www.buzzfeed.com/ishabassi/troye-sivan-leak-new-music-working-withfreelance-artists [Accessed 25.03.20]

Cooper-Cunningham, D. (2020). Drawing Fear of Difference: Race, Gender, and National Identity in Ms. Marvel Comics. Millennium: Journal of International Studies, vol. 48(2), pp. 165-197. http://dx.doi.org/10.1177/0305829819889133

Halberstam, J. (2012). Gaga feminism: Sex, gender, and the end of normal, Boston, Beacon Press.

Hammil, J. (2020). Glasgow Elvis impersonator performs coronavirus lockdown gig from his balcony. The Herald. Available at: https://www.heraldscotland.com/news/18346109.glasgow-elvis-impersonator-performs-coronaviruslockdown-gig-balcony/ [Accessed 01.04.20]

Hanely, L. 2020. Lockdown has laid bare Britain's class divide. Guardian, 7 April 2020. Available at: https://www.theguardian.com/commentisfree/2020/apr/07/lockdown-britain-victorian-class-divide [Accessed 07.04.20]

Harman, S. (2019). Seeing Politics: Film, Visual Method, and International Relations. Qeuebec: McGill-Queen's University Press.

Jonze, T. (2011). Lady Gaga: Born This Way - review. Guardian. Available at: https://www.theguardian.com/music/2011/may/18/lady-gaga-born-this-way-review [Accessed 10.04.20]

Kearney, C. (2020). Italians sing patriotic songs from their balconies during coronavirus lockdown. Guardian. Available at: https://www.theguardian.com/world/2020/mar/14/italians-sing-patriotic-songs-from-their-balconiesduring-coronavirus-lockdown [Accessed 15.03.20] 
Moore, S. (2020). This crisis has changed our experience of home - and exposed the deep pain of poor housing. Guardian. Available at: https://www.theguardian.com/commentisfree/2020/apr/06/coronavirus-crisis-garden-housing-tower-block-home [Accessed 07.04.2020]

O'Carroll, L., Walker, P. and Brooks, L. (2020). UK to close door to non-English speakers and unskilled workers. Guardian. Available at: https://www.theguardian.com/uk-news/2020/feb/18/uk-to-close-door-to-non-english-speakers-and-unskilled-workers [Accessed 20.02.20]

Puar, J. (2007). Terrorist assemblages: Homonationalism in queer times. Durham: Duke University Press.

Puar, J. and Rai, A. (2002). Monster, Terrorist, Fag: The War on Terrorism and the Production of Docile Patriots. Social Text, vol. 20(3), pp. 117-148. http://dx.doi.org/10.1215/01642472-20-3_72-117

Rolling Stone (2020). Charli XCX Announces 'DIY 'Quarantine Album 'How I'm Feeling Now'. Rolling Stone. Available at: https://www.rollingstone.com/music/music-news/charli-xcx-how-im-feeling-now-979219/ [Accessed 08.04.20]

Tilden, I. (2020). Bittersweet symphony: the best lockdown orchestras and choirs online. Guardian. Available at: https://www.theguardian.com/music/2020/apr/15/bittersweet-symphony-the-best-lockdown-orchestras-and-choirs-online [Accessed 16.04.20]

Weber, C. (2011). I am an American: filming the fear of difference. Bristol: Intellect. 